\title{
First siloxane tethered paracyclophane
}

\author{
Sundarraj Sudhakar a, Gene-Hsiang Lee a, Yu Wang a, Jui-Hung Hsu a, \\ Tien-Yau Luh ${ }^{\mathrm{a}, \mathrm{b}, *}$ \\ a Department of Chemistry, National Taiwan University, Taipei 106, Taiwan, ROC \\ b Institute of Chemistry, Academia Sinica, Nankang, Taipei, Taiwan 115, ROC
}

Received 9 July 2001; accepted 4 September 2001

\begin{abstract}
Treatment of 1,4-bis \{[dimethyl(i-propoxy)silyl]vinyl\}benzene (3) with water in the presence of base results in the formation of a siloxane tethered paradivnylbenzene cyclophane 2. The structure of $\mathbf{2}$ was confirmed by X-ray crystallography. UV and fluorescence spectra were measured and interaction between chromophores may occur. (C) 2002 Elsevier Science B.V. All rights reserved.
\end{abstract}

Keywords: Paracyclophanes; Siloxane; UV spectrum; Fluorescence; X-ray structure

\section{Introduction}

Cyclophanes have received much attention over the last decades because of the particular properties of this class of compound, such as effects of strain on structure and reactivity, transannular interactions, and the potential to act as hosts for certain guest molecules [1,2]. A large number of cyclophanes have been synthesized for the purpose of investigating their peculiar electronic and spectroscopic properties due to their interesting stereochemistry. In particular, cyclophanes in which the aromatic units are linked at the 1,4-positions by saturated as well as unsaturated bridges have been studied extensively [1]. Although carbon is the common bridging element in many of the cyclophanes, other elements such as silicon, nitrogen, phosphorus, oxygen, sulfur, etc. could also act as bridging elements to give additional chemical and physical properties. Though the literature is abundant with respect to cyclic siloxanes [3] and with some references to silicon bridged macrocycles [4], the information available on cyclophanes having a silicon oxygen bridge is scanty [5]. To the best of our knowledge, only dialkoxysilane bridged metacyclophanes are known [5]. Despite the fact that silicon presents many advantages for the design of new macrocycles, in particular, it can serve as an additional coordi-

\footnotetext{
* Corresponding author. Tel.: +886-2-27898500; fax: + 886-226511488.

E-mail address: tyluh@chem.sinica.edu.tw (T.-Y. Luh).
}

nation site [6] as well as the means of increasing the solubility and flexibility. Recently we have been interested in investigating the photophysical properties of silylene-spaced divinylarene copolymers 1 with a view to understand the intramolecular $\pi-\pi$ interactions [7]. We envisaged preparing a cyclic analogue in order to understand better the nature of interactions. Herein we report the first example of a siloxane-tethered cyclophane $\mathbf{2}$.<smiles>CCC=C[Al]C=C[Si](C)(C)C=C[Te]C=C[Si]1(C)CC1</smiles>

1

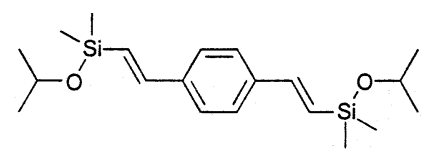

3

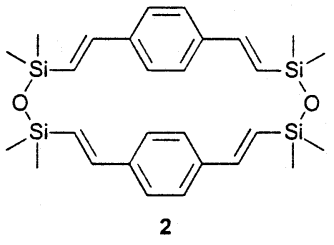

2

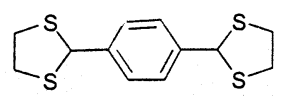

4 
Table 1

Effect of various reaction parameters on the yield of the cyclophane 2

\begin{tabular}{|c|c|c|}
\hline Parameter varied & Variation factor & Yield of $2(\%)$ \\
\hline Solvent ${ }^{\mathrm{a}}$ & 100:0 & 35 \\
\hline \multirow[t]{4}{*}{ (IPA-THF) } & $75: 25$ & 23 \\
\hline & $50: 50$ & 7 \\
\hline & $25: 75$ & - \\
\hline & $0: 100$ & - \\
\hline \multirow[t]{5}{*}[\mathrm{NaOH}]{$^{b}$} & $1 \mathrm{~mol} \%$ & - \\
\hline & $3 \mathrm{~mol}^{\%} \%$ & 7 \\
\hline & $7 \mathrm{~mol}^{\%} \%$ & 23 \\
\hline & $9 \mathrm{~mol} \%$ & 27 \\
\hline & $15 \mathrm{~mol} \%$ & 37 \\
\hline \multirow[t]{4}{*}[\mathrm{H}_{2}\mathrm{O}]{$^{\mathrm{c}}$} & $1.4 \mathrm{~mol}^{\%} \%$ & 22 \\
\hline & $4.1 \mathrm{~mol}^{\%} \%$ & 34 \\
\hline & $5.5 \mathrm{~mol}^{\%} \%$ & 38 \\
\hline & $6.9 \mathrm{~mol}^{\%} \%$ & 39 \\
\hline \multirow[t]{4}{*}[3]{$^{\mathrm{d}}$} & $0.03 \mathrm{M}$ & 32 \\
\hline & $0.15 \mathrm{M}$ & 35 \\
\hline & $0.30 \mathrm{M}$ & 46 \\
\hline & $0.60 \mathrm{M}$ & 46 \\
\hline \multirow[t]{5}{*}{ Catalyst $^{\mathrm{e}}$} & $\mathrm{NaOH}$ & 35 \\
\hline & $\mathrm{KOH}$ & 36 \\
\hline & $\mathrm{HCl}$ & 19 \\
\hline & PTSA & 16 \\
\hline & TBAF & 22 \\
\hline
\end{tabular}

a Monomer $=1 \mathrm{mmol}, \mathrm{H}_{2} \mathrm{O}=2.77 \mathrm{mmol}, \mathrm{NaOH}=5 \mathrm{~mol} \%$, IPA$\mathrm{THF}=3.6 \mathrm{ml}$.

${ }^{\mathrm{b}}$ Monomer $=1 \mathrm{mmol}, \mathrm{H}_{2} \mathrm{O}=2.77 \mathrm{mmol}, \mathrm{IPA}=3.6 \mathrm{ml}$.

${ }^{\mathrm{c}}$ Monomer $=1 \mathrm{mmol}, \mathrm{NaOH}=5 \mathrm{~mol} \%, \mathrm{IPA}=3.6 \mathrm{ml}$.

${ }^{\mathrm{d}}$ Monomer $=1 \mathrm{mmol}, \mathrm{NaOH}=5 \mathrm{~mol} \%, \mathrm{H}_{2} \mathrm{O}=2.8 \mathrm{mmol}$.

${ }^{\mathrm{e}}$ Monomer $=1 \mathrm{mmol}$, catalyst $=5 \mathrm{~mol}^{\%}, \mathrm{H}_{2} \mathrm{O}=2.8 \mathrm{mmol}$, IPA $3.6 \mathrm{ml}$.

Compound 3 was prepared according to our earlier reported procedure utilizing the nickel-catalyzed cross coupling between $\mathrm{Me}_{2}(i-\mathrm{PrO}) \mathrm{SiCH}_{2} \mathrm{MgCl}$ and bisdithioacetal 4 [7,8]. The synthesis of cyclophane 2 was achieved in a single step by the hydrolytic condensation of 3 under basic conditions in the presence of water ${ }^{1}$. Although the siloxane formation can be catalyzed by an acid or a base [9], a significant amount of oligomer/ polymer $5\left(M_{\mathrm{n}}=2000-3000 \mathrm{PDI}=1.2-2.1\right)$ was also formed. Table 1 summarizes various reaction conditions and the yield of $\mathbf{2}$. The formation of $\mathbf{2}$ was favored when the reaction was carried out in isopropanol under basic conditions. Increasing the catalyst concentration also slightly increased the yield of 2 , but a better yield (46\%) was obtained by increasing the concentration of water $(2.8 \mathrm{~mol} \%)$ and also the concentration of $3(0.3 \mathrm{M})$. It is known that bis(alkoxysilane) derivatives can readily form polysiloxanes under these reaction conditions $[3,9]$. The uniqueness of the structure of the substrate $\mathbf{3}$ may preferentially afford the cyclophane 2. It is interesting to note that the mass spectral analyses of the oligomer/polymer revealed that no trimeric or tetrameric products were formed under these conditions.

\footnotetext{
${ }^{1}$ General procedure for the synthesis of cyclophane 2: silane 3 $(0.36 \mathrm{~g}, 1 \mathrm{mmol})$ was dissolved in $1.8 \mathrm{ml}$ of isopropanol, freshly distilled from $\mathrm{Na}$ and to this was added $0.05 \mathrm{ml}$ of aq. $1 \mathrm{~N} \mathrm{NaOH}$ solution ( $\mathrm{NaOH}$ : $0.05 \mathrm{mmol} ; \mathrm{H}_{2} \mathrm{O}: 2.8 \mathrm{mmol}$ ) dissolved in $1.8 \mathrm{ml}$ of isopropanol and stirred at $30{ }^{\circ} \mathrm{C}$ for $24 \mathrm{~h}$. The solid obtained was filtered, washed with isopropnanol and recrystallized from a $\mathrm{CHCl}_{3}-$ $\mathrm{MeOH}$ solution to afford the cylophane $\mathbf{2}$ as colorless crystals: m.p. $>190{ }^{\circ} \mathrm{C}$ (dec.), ${ }^{1} \mathrm{H}-\mathrm{NMR}\left(400 \mathrm{MHz}, \mathrm{CDCl}_{3}\right) \delta 0.23$ (s, 24H), 6.35 (d, $J=19.2 \mathrm{~Hz}, 4 \mathrm{H}), 6.77$ (d, $J=19.2 \mathrm{~Hz}, 4 \mathrm{H}), 7.04$ (s, 8H); ${ }^{13} \mathrm{C}-\mathrm{NMR}\left(100 \mathrm{MHz}, \mathrm{CDCl}_{3}\right) \delta 0.2,126.5,129.7,137.8,143.1$; ${ }^{29} \mathrm{Si}-\mathrm{NMR} \quad\left(79.5 \mathrm{MHz}, \mathrm{CDCl}_{3}\right) \quad \delta \quad-1.53 ; \quad \mathrm{MS} m / z \quad 520$; $\lambda_{\max }\left(\mathrm{CHCl}_{3}\right)=290 \mathrm{~nm}$; Anal. Calc. for $\mathrm{C}_{28} \mathrm{H}_{40} \mathrm{O}_{2} \mathrm{Si}_{4}: \mathrm{C}, 64.55 ; \mathrm{H}$, 7.74. Found: C, 64.28; H, 8.06\%.
}
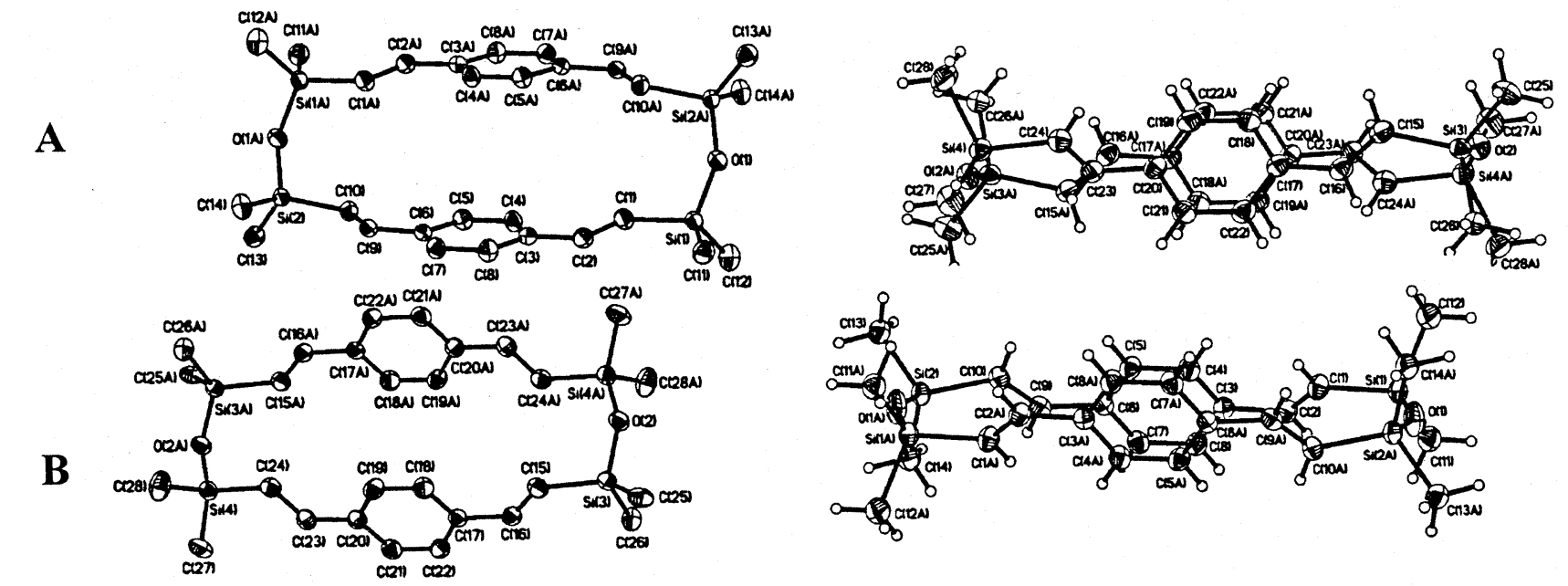

Fig. 1. ORTEP view of $\mathbf{2}$ showing the two different conformers $\mathbf{A}$ and $\mathbf{B}$ and their side view observed from the plane of the benzene ring. (Selected

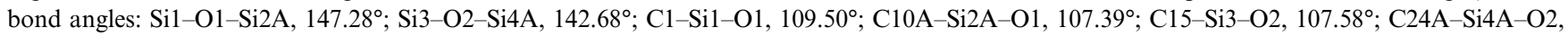
$\left.109.78^{\circ}\right)$. 


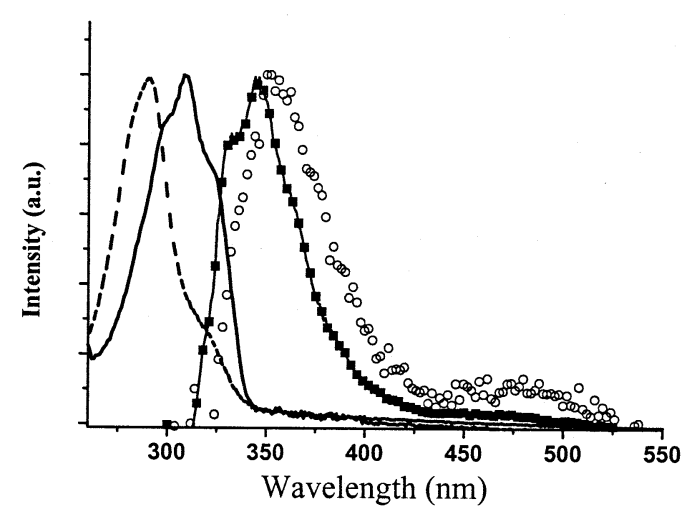

Fig. 2. UV absorption and fluorescence spectra of $\mathbf{2}$ (dash line for $\mathrm{UV}$, and clear dot for fluorescence) and $\mathbf{3}$ (solid line for UV, and solid dot with line for fluorescence). The fluorescence yield of $\mathbf{2}$ is about one order of magnitude lower than that of $\mathbf{3}$.

The ${ }^{1} \mathrm{H}-\mathrm{NMR}$ spectrum of $\mathbf{2}$, showed a singlet at $\delta$ 7.04, which appeared at a higher field than that of the corresponding monomer $3(\delta$ 7.40). Essentially no changes in the ${ }^{1} \mathrm{H}-\mathrm{NMR}$ spectrum in $\mathrm{CD}_{2} \mathrm{Cl}_{2}$ solution were observed at low temperature (up to $-95{ }^{\circ} \mathrm{C}$ ). This result highlights the flexibility of $\mathbf{2}$, the two phenylene rings flipping continuously due to the low energy barrier. The ${ }^{29} \mathrm{Si}-\mathrm{NMR}$ of 2 shows a singlet at $\delta-1.53$. The X-ray structure of $\mathbf{2}$ reveals that the molecules are packed in the crystal in dual conformations $\mathbf{A}$ and $\mathbf{B}$ (Fig. 1) $)^{2}$. In A, the two benzene rings are separated by $3.66 \AA$ and the $\mathrm{Si}-\mathrm{O}-\mathrm{Si}$ bond angle is $147.3^{\circ}$. The distance between two benzene rings in $\mathrm{B}$ is $3.97 \AA$ and the corresponding $\mathrm{Si}-\mathrm{O}-\mathrm{Si}$ angle is $142.7^{\circ}$. The corresponding side view of structures $\mathbf{A}$ and $\mathbf{B}$ is also shown in Fig. 1 for comparison. It is interesting to note that the benzene rings in each of these structures are planar and lie parallel to each other. The planes of the double bonds are tilted inwards which could lead to less conjugation in $\mathbf{2}$ in comparison with the conjugation lengths of $\mathbf{3}$ and $\mathbf{5}$.

The UV absorption and fluorescence spectra for $\mathbf{2}$ and 3 are shown in Fig. 2. It is noteworthy that $\lambda_{\max }$ for $\mathbf{2}$ is slightly blue shifted when compared with that of $\mathbf{3}$. Interaction between chromophores in paracyclophanes has been sporadically investigated. Both batho- and hypsochromic shifts in their absorption spectra have been observed depending on the nature of the chromophore [10,11]. As described earlier, the conjugation length in $\mathbf{2}$ may be reduced due to ring strain of the cyclophane skeleton, which will result in hypsochromic shift in the UV spectrum. Alternatively, H-type aggre-

\footnotetext{
${ }^{2}$ Crystal data for 2: $\mathrm{C}_{28} \mathrm{H}_{40} \mathrm{O}_{2} \mathrm{Si}_{4}, \quad M=520.96$, triclinic, space group $P \overline{1}, \quad a=8.8009(3), \quad b=12.6881(6), \quad c=14.2737(6), \quad \alpha=$ 93.865(1), $\beta=91.300(1), \gamma=107.045(1)^{\circ}, V=1518.91 \AA^{3}, Z=2, T=$ $150 \mathrm{~K}, \mu\left(\mathrm{Mo}-\mathrm{K}_{\alpha}\right)=5.94 \mathrm{~cm}^{-1}, 21180$ reflections measured, 6957 independent reflections, $R_{\text {int }}=0.0382$, final $R_{1}=0.0376, w R_{2}=$ $0.0918[I>2 \sigma(I)]$.
}

gation between chromophores in 2 [12] may lead to blue shift in the absorption spectrum. In addition, the fluorescence intensity for $\mathbf{2}$ is much lowered by comparison with that of $\mathbf{3}$. These results suggest that interaction between chromophores may occur.

In summary, a single step synthesis towards a siloxane tethered paradivinylbenzene cyclophane has been achieved by the base catalyzed hydrolytic condensation of the monomeric bis(isopropoxy-silane). Further investigation on the photophysics as well as on the structural variation of the cyclophane is under progress.

\section{Supplementary material}

Crystallographic data for the structural analysis have been deposited with the Cambridge Crystallographic Data Centre, CCDC no. 166407 for compound 2. Copies of this information may be obtained free of charge from The Director, CCDC, 12 Union Road, Cambridge CB2 IEZ, UK (Fax: 44-1223-336033; email: deposit@ccdc.cam.ac.uk or www: http://www.ccdc. cam.ac.uk).

\section{Acknowledgements}

Support from the National Science Council and the Ministry of Education of the Republic of China is gratefully acknowledged.

\section{References}

[1] (a) P.M. Keehn, S.M. Rosenfeld (Eds.), Cyclophanes, vol. 1 and 2, Academic Press, New York, 1983;

(b) F. Diederich, in: Cyclophanes, RSC, Cambridge, UK, 1991; (c) F. Vögtle, in: Cyclophane Chemistry, Wiley, New York, 1993.

[2] (a) F. Vögtle, Supramolecular Chemistry, Wiley, Chichester, 1989;

(b) B. Dietrich, P. Viout, J.-M. Lehn, Macrocyclic Chemistry: Aspects of Organic and Inorganic Supramolecular Chemistry, VCH, New York, 1993;

(c) J.-M. Lehn, Supramolecular Chemistry, Wiley, Chichester, 1995.

[3] (a) J.I. Kroschwitz, M. Howe-Grant (Eds.), Silicon compounds (Silicones), Kirk-Othmer Encyclopedia of Chemical Technology, vol. 22, 4th ed., Wiley, New York, 1997, p. 1;

(b) C. Burger, F.-H. Kreuzer, Polysiloxanes and polymers containing siloxane groups, in: H.R. Kricheldorf (Ed.), Silicon in Polymer Synthesis, Springer, Berlin, 1996, p. 113, Chapter 3.

[4] (a) C. Kaes, M.W. Hosseini, R. Ruppert, A.D. Cian, J. Fischer, Tetrahedron Lett. 35 (1994) 7233;

(b) C. Kaes, M.W. Hosseini, A.D. Cian, J. Fischer, Chem. Commun. (1997) 2229;

(c) B. König, M. Rödel, P. Bubenitschek, P.G. Jones, Angew. Chem. Int. Ed. Engl. 34 (1995) 661;

(d) N. Launay, F. Denat, A.-M. Caminade, J.-P. Majoral, J. Dubac, Bull. Soc. Chim. Fr. 131 (1994) 758. 
[5] (a) T.K. Prakasha, A. Chandrasekaran, R.O. Day, R.R. Holmes, Inorg. Chem. 35 (1996) 4342;

(b) B. Rezzonico, M. Grignon-Dubois, M. Laguerre, J.-M. Leger, Organometallics 17 (1998) 2656.

[6] M.E. Jung, H. Xia, Tetrahedron Lett. 29 (1988) 297.

[7] R.-M. Chen, K.-M. Chien, K.-T. Wong, B.-Y. Jin, T.-Y. Luh, J.-H. Hsu, W. Fann, J. Am. Chem. Soc. 119 (1997) 11321.

[8] R.-M. Chen, T.-Y. Luh, Tetrahedron 54 (1998) 1197.
[9] M.A. Brook, Silicon in Organic, Organometallic, and Polymer Chemistry, Wiley, New York, 2000.

[10] S.M.H. Kabir, M. Iyoda, Chem. Commun. (2000) 2329.

[11] G.C. Bazan, W.J. Oldham Jr., R.L. Lachicotte, S. Tretiak, V. Chernyak, S. Mukamel, J. Am. Chem. Soc. 120 (1998) 9188 and references therein.

[12] D. Oelkrug, A. Tompert, H.-J. Egelhaaf, M. Hanack, E. Steinhuber, M. Hohloch, H. Meier, U. Stalmach, Synth. Met. 83 (1996) 231 and references therein. 